\title{
Catenuloplanes crispus (Petrolini et al. 1993) comb. nov.: incorporation of the genus Planopolyspora Petrolini 1993 into the genus Catenuloplanes Yokota et al. 1993 with an amended description of the genus Catenuloplanes
}

\author{
Takuji Kudo, Yuki Nakajima and Ken-ichiro Suzuki
}

\begin{abstract}
Author for correspondence: Takuji Kudo. Tel: +8148462 1111. Fax: +81484624617. e-mail: kudo@jcm.riken.go.jp
\end{abstract}

Japan Collection of Microorganisms, The Institute of Physical and Chemical Research (RIKEN), Wako, Saitama 351-0198, Japan

\begin{abstract}
The taxonomic position of the genus Planopolyspora comprising a single species, Planopolyspora crispa, was reviewed. This genus was originally characterized by formation of long, curly and sometimes branching sporangia containing numerous zoospores arranged in a single row and by the presence of meso-diaminopimelic acid and madurose (3-0-methyl-D-galactose) in wholecell hydrolysates. However, our chemotaxonomic analyses of the type strain of $P$. crispa did not agree with the original description. The peptidoglycan contained L-lysine but not meso-diaminopimelic acid, and the whole-cell hydrolysate contained xylose as the characteristic sugar but not madurose. These characteristics and other chemotaxonomic profiles (e.g. menaquinone, phospholipid and cellular fatty acid compositions) of the genus Planopolyspora coincided with those of the genus Catenuloplanes. These two genera also had very similar morphological characteristics, but in the original description of the genus Catenuloplanes the presence of sporangia was not referred to. This difference is considered to originate from a divergence of views owing to the ambiguity of the definition of the term 'sporangium' in actinomycete morphology. Phylogenetic analysis based on 165 rDNA sequences also supported the proposal that the genera Planopolyspora and Catenuloplanes should be combined into one genus. Levels of DNA relatedness among the type strains of $P$. crispa and six Catenuloplanes species and their cultural, physiological and biochemical characteristics indicated that $P$. crispa should be classified as an independent species of the genus Catenuloplanes, which has priority over the genus Planopolyspora. Therefore, it is proposed that Planopolyspora crispa be transferred to the genus Catenuloplanes as Catenuloplanes crispus comb. nov.
\end{abstract}

Keywords: Catenuloplanes crispus, Planopolyspora crispa, Actinomycetales, Micromonosporaceae, actinomycetes

\section{INTRODUCTION}

The genus Planopolyspora and its type species Planopolyspora crispa were described by Petrolini et al.

Abbreviation: $\mathrm{A}_{2} \mathrm{pm}, 2$,6-diaminopimelic acid.

The DDBJ/EMBU/GenBank accession number for the 16S rDNA sequence of Planopolyspora crispa JCM $9312^{\mathrm{T}}$ is AB024701. (1993a) for a single actinomycete strain isolated from decomposed leaf litter of Prunus persica. This genus was characterized by production of tubular, curly, twisted and sometimes branched sporangia that developed in clusters on the colony surface. The sporangia contained numerous spores arranged in a single row and the sporangiospores became motile by subpolar flagellation after release into water. According to chemotaxonomic analyses in the original de- 
Table 1. Cultural, physiological and biochemical characteristics of the type strains of Planopolyspora and Catenuloplanes species

All strains decomposed casein, aesculin and urea; none decomposed adenine, DNA, hypoxanthine, tyrosine and xanthine. All strains utilized L-arabinose, D-cellobiose, D-fructose, D-galactose, D-glucose, glycerol, myo-inositol, D-lactose, maltose, D-mannitol, D-mannose, L-rhamnose, salicin, starch, sucrose, D-trehalose and D-xylose; none utilized adonitol, dulcitol, $i$-erythritol and Dmelezitose. All strains utilized fumarate, L-malate and succinate; none utilized benzoate, citrate, mucate, oxalate and L-tartrate. All strains produced acid from L-arabinose, D-fructose, D-galactose, D-glucose, myo-inositol, L-rhamnose, sucrose and D-xylose; none produced acid from D-melezitose, methyl $\alpha$-D-glucoside and L-sorbose. All strains were susceptible to novobiocin and kanamycin at $20 \mu \mathrm{g} \mathrm{ml}^{-1}$.

\begin{tabular}{|c|c|c|c|c|c|c|c|}
\hline Characteristic & $\begin{array}{c}\text { P. crispa } \\
\text { JCM 9312 }\end{array}$ & $\begin{array}{l}\text { C. atrovinosus } \\
\text { JCM } 9535^{\mathrm{T}}\end{array}$ & $\begin{array}{l}\text { C. castaneus } \\
\text { JCM } 9537^{\mathrm{T}}\end{array}$ & $\begin{array}{l}\text { C. indicus } \\
\text { JCM 9534 }\end{array}$ & $\begin{array}{l}\text { C. japonicus } \\
\text { JCM 9106 }^{\top}\end{array}$ & $\begin{array}{l}\text { C. nepalensis } \\
\text { JCM 9536 }\end{array}$ & 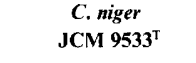 \\
\hline \multicolumn{8}{|l|}{ Colour of colony on: } \\
\hline Oatmeal agar (ISP-3) & 3 ne (topaz) & 4 lc (dusty orange) & 3 nc (amber) & 4 ng (light brown) & $3 \mathrm{lc}$ (amber) & $4 \mathrm{nc}$ (russet orange) & 4 ng (light brown) \\
\hline Inorganic salts/starch agar (ISP-4) & $\begin{array}{l}4 \mathrm{ca} \text { (pearl } \\
\text { pink) }\end{array}$ & $3 \mathrm{gc}($ light tan) & $4 \mathrm{ca}$ (pearl pink) & $\begin{array}{l}4 \text { ic (pastel } \\
\text { orange) }\end{array}$ & $\begin{array}{l}4 \text { ca (pearl } \\
\text { pink) }\end{array}$ & 4 ic (pastel orange) & 4 le (maple) \\
\hline Glycerol/asparagine agar (ISP-S) & $\begin{array}{l}3 \text { ga (melon } \\
\text { yellow) }\end{array}$ & 4 le (maple) & $\begin{array}{l}4 \text { na (bright } \\
\text { orange) }\end{array}$ & 4 ia (light orange) & $\begin{array}{l}4 \text { na (bright } \\
\text { orange) }\end{array}$ & 4 na (bright orange) & 4 na (bright orange) \\
\hline Yeast extract/starch agar & 2 gc (bamboo) & 2 ec (sand) & $3 \mathrm{gc}$ (light tan) & 4 ne (luggage tan) & $3 \mathrm{gc}$ (light tan) & $3 \mathrm{gc}($ light $\tan )$ & 3 ge (light tan) \\
\hline Bennett's agar containing maltose & $\begin{array}{l}4 \mathrm{ca} \text { (pearl } \\
\text { pink) }\end{array}$ & $2 \mathrm{gc}$ (bamboo) & $3 \mathrm{gc}$ (light tan) & $\begin{array}{l}4 \text { ec (light rose } \\
\text { beige) }\end{array}$ & $\begin{array}{l}4 \text { ca (pearl } \\
\text { pink) }\end{array}$ & Colourless & 3 gc (light $\tan )$ \\
\hline \multicolumn{8}{|l|}{ Soluble pigment in: } \\
\hline Glycerol/asparagine agar (ISP-5) & Yellowish & None & None & Yellowish & None & None & None \\
\hline Nutrient agar & None & Brownish & None & None & None & None & Brownish \\
\hline \multicolumn{8}{|l|}{ Decomposition of: } \\
\hline Elastin & + & \pm & - & + & + & - & + \\
\hline Testosterone & + & + & - & + & + & - & + \\
\hline \multicolumn{8}{|l|}{ Utilization of: } \\
\hline Methyl $\alpha$-D-glucoside & - & - & - & - & + & - & + \\
\hline D-Raffinose & - & - & - & - & + & + & + \\
\hline D-Ribose & \pm & + & - & + & \pm & \pm & + \\
\hline \multicolumn{8}{|l|}{ Acid from: } \\
\hline Melibiose & - & + & + & + & - & + & + \\
\hline D-Ribose & - & + & - & - & - & - & - \\
\hline \multicolumn{8}{|l|}{ Tolerant to $\left(20 \mu \mathrm{g} \mathrm{ml}^{-1}\right)$ : } \\
\hline Ampicillin & - & + & - & - & - & - & + \\
\hline Benzylpenicillin & - & + & + & - & - & + & - \\
\hline Cephalexin & - & + & - & + & - & - & + \\
\hline Growth in $2 \%(\mathrm{w} / \mathrm{v}) \mathrm{NaCl}$ & - & - & - & + & + & - & + \\
\hline
\end{tabular}

scription, meso-2,6-diaminopimelic acid (meso- $\mathrm{A}_{2} \mathrm{pm}$ ) and madurose (3-O-methyl-D-galactose) were detected in the whole-cell hydrolysate; the authors classified their new genus into the 'maduromycete' group, the tentative name for the madurose-containing taxa (Goodfellow, 1989). Other chemotaxonomic properties of this genus such as menaquinone, phospholipid and cellular fatty acid compositions have not been determined so far. The genus Planopolyspora and its type species $P$. crispa were cited in list no. 47 for validation of the publication of new names and new combinations previously effectively published outside the International Journal of Systematic Bacteriology (Petrolini et al., 1993b). At present, P. crispa is still the single member of the genus Planopolyspora.

Prior to the validation of the genus Planopolyspora, the genus Catenuloplanes was proposed by Yokota et al. (1993) as a new genus and revived name. Strains belonging to this genus bore arthrospores arranged in chains arising from the substrate mycelium or the aerial mycelium but did not produce sporangia. The spores showed motility by peritrichous fiagellation after release into water. The cell wall contained Llysine but not $\mathrm{A}_{2} \mathrm{pm}$ as the diamino acid in the peptidoglycan. The most diagnostic cell wall sugar of the genus was xylose but madurose was not detected.
The major menaquinones were reported to be MK$9\left(\mathrm{H}_{8}\right)$ and $\mathrm{MK}-10\left(\mathrm{H}_{8}\right)$ and characteristic phospholipids were phosphatidylethanolamine and phosphatidylcholine [type PIII of Lechevalier et al. (1977)]. In addition to the type species Catenuloplanes japonicus, five species Catenuloplanes niger, Catenuloplanes indicus, Catenuloplanes atrovinosus, Catenuloplanes castaneus and Catenuloplanes nepalensis were proposed by Tamura et al. (1995). Subsequently, the genus Catenuloplanes was classified in the family Micromonosporaceae Krasil'nikov 1938 emend. Koch et al. 1996 on the basis of 16S rDNA sequences (Koch et al., 1996).

Although the genera Planopolyspora and Catenuloplanes were different in terms of formation of sporangia and compositions of cell wall amino acids and whole-cell sugars, scanning electron micrographs associated with the original descriptions of both genera indicated that these two genera had quite similar morphological properties. In this paper, we review the taxonomic positions of the type strains of $P$. crispa and Catenuloplanes species from morphological, chemotaxonomic and phylogenetic points of view and propose incorporation of the genus Planopolyspora into the genus Catenuloplanes as Catenuloplanes crispus comb. nov. 
Catenuloplanes crispus comb. nov.

\section{METHODS}

Bacterial strains and cultivation. The following strains were used in this study: $P$. crispa JCM $9312^{\mathrm{T}}\left(=\right.$ ATCC $51431^{\mathrm{T}}=$ DSM $44128^{\mathrm{T}}=$ IFO $15622^{\mathrm{T}}=$ IPV $2867^{\mathrm{T}}=$ NCB $\left.1173^{\mathrm{T}}\right), C$. japonicus $\mathrm{JCM} 9106^{\mathrm{T}}\left(=\mathrm{ATCC} 31637^{\mathrm{T}}=\mathrm{DSM} 44102^{\mathrm{T}}=\right.$ IFO $14176^{\mathrm{T}}=$ NCIMB $13394^{\mathrm{T}}=$ VKM Ac-875 $)$, C. atrovinosus JCM $9535^{\mathrm{T}}\left(=\right.$ ATCC $\left.700015^{\mathrm{T}}=\mathrm{IFO} 15579^{\mathrm{T}}\right), C$. castaneus $\mathrm{JCM} 9537^{\mathrm{T}}\left(=\mathrm{ATCC} 700016^{\mathrm{T}}=\mathrm{IFO} 15584^{\mathrm{T}}\right), C$. indicus JCM 9534 $\left(=\right.$ ATCC $\left.700014^{\mathrm{T}}=\mathrm{IFO} 15575^{\mathrm{T}}\right), C$. nepalensis JCM 9536 $\left(=\right.$ ATCC $\left.700017^{\mathrm{T}}=\mathrm{IFO} 15583^{\mathrm{T}}\right)$ and $C$. niger JCM $9533^{\mathrm{T}}\left(=\mathrm{ATCC} 31638^{\mathrm{T}}=\mathrm{IFO} 14177^{\mathrm{T}}\right)$. These organisms were routinely cultivated on yeast extract/ starch agar containing 2 g yeast extract (Difco), 10 g soluble starch and $15 \mathrm{~g}$ agar in $1000 \mathrm{ml}$ distilled water $(\mathrm{pH} \mathrm{7.3)}$ at $28^{\circ} \mathrm{C}$ for $14 \mathrm{~d}$ and maintained at $8{ }^{\circ} \mathrm{C}$. Biomasses for chemotaxonomic analyses and DNA preparation were obtained from cultures grown in yeast extract/glucose broth containing $10 \mathrm{~g}$ yeast extract and $10 \mathrm{~g}$ D-glucose in $1000 \mathrm{ml}$ distilled water $\left(\mathrm{pH} \mathrm{7.2)}\right.$ on a rotary shaker at $30^{\circ} \mathrm{C}$.

Morphology. Cultures were grown on oatmeal/nitrate agar containing $3 \mathrm{~g}$ powdered oatmeal, $0.2 \mathrm{~g} \mathrm{KNO}_{3}, 0.5 \mathrm{~g}$ $\mathrm{K}_{2} \mathrm{HPO}_{4}, 0.2 \mathrm{~g} \mathrm{MgSO}_{4} .7 \mathrm{H}_{2} \mathrm{O}$ and $15 \mathrm{~g}$ agar in $1000 \mathrm{ml}$ distilled water $(\mathrm{pH} 7.0)$ for $14 \mathrm{~d}$ at $28^{\circ} \mathrm{C}$ and observed with light and scanning electron microscopes. The specimens for scanning electron microscopy were prepared as described previously (Itoh et al., 1989).

Cultural, physiological and biochemical characteristics. Cultural characteristics were tested by using $21 \mathrm{~d}$ cultures grown at $28{ }^{\circ} \mathrm{C}$ on four selected agar media (Table 1). Colour designations and colour names of colonies were described by comparison with colour chips from the Colour Harmony Manual (Jacobson et al., 1958). Decomposition of urea was examined on Christensen agar (Difco) supplemented with $2 \%(\mathrm{w} / \mathrm{v})$ urea and decomposition of the other compounds was examined on the basal medium of Gordon et al. (1974). Utilization of carbohydrates as sole carbon sources was tested by using neutralized yeast nitrogen base without amino acids (Difco) as a basal medium according to the method of Stevenson (1967). Utilization of organic acids was examined on the defined medium of Gordon et al. (1974). Resistance to $\mathrm{NaCl}$ was determined on yeast extract/starch agar supplemented with various concentrations $(0-10 \%$, $\mathrm{w} / \mathrm{v}$ ) of $\mathrm{NaCl}$ at $28^{\circ} \mathrm{C}$. Susceptibility to various antibiotics was also determined on the same agar media supplemented with antibiotics $\left(20 \mu \mathrm{g} \mathrm{ml}^{-1}\right)$.

Chemotaxonomy. Cell walls were purified and hydrolysed by the methods of Kawamoto et al. (1981) and their amino acid composition was analysed with an automatic amino acid analyser. To determine the configurations of the amino acids, hydrolysates of purified cell walls were reacted with a chiral reagent $[(+)-1-(9-$-fluorenyl)ethyl chloroformate] and analysed by HPLC as described by Einarsson \& Josefsson (1987). The $N$-acyl group of muramic acid in the peptidoglycan was determined by the method of Uchida \& Aida (1984). Samples for analysis of whole-cell sugars were prepared as described by Lechevalier \& Lechevalier (1970) and were analysed by the HPLC method of Mikami \& Ishida (1983). Phospholipids were extracted and identified by the method of Minnikin et al. (1984). Methyl esters of cellular fatty acids were prepared by the direct transmethylation method with methanolic hydrochloride and were analysed by GLC as described previously (Suzuki \& Komagata, 1983). This methyl ester preparation was also used for detection of mycolic acids by application to silica gel TLC developed with $n$-hexane/dimethylether $(4: 1)$. Isoprenoid

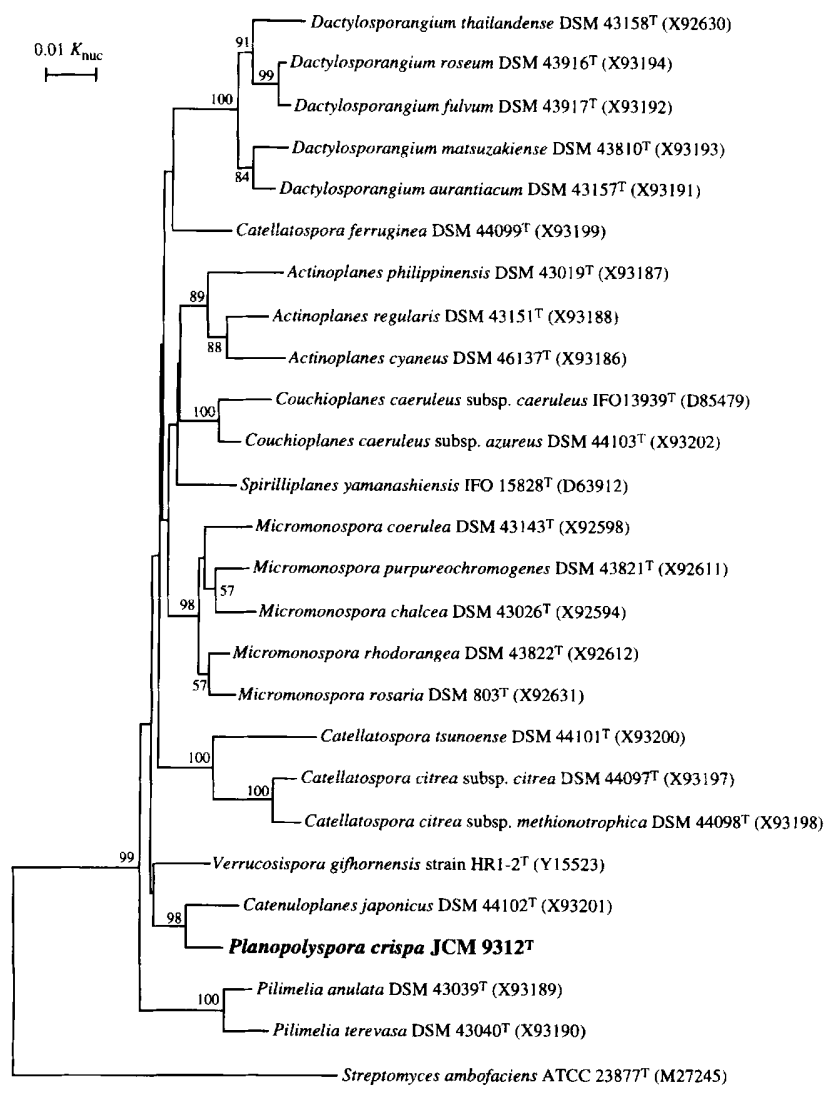

Fig. 1. Phylogenetic relationship of Planopolyspora crispa JCM $9312^{\top}$ and some members of the family Micromonosporaceae based on 16S rDNA sequence comparison. The numbers on the tree indicate bootstrap values greater than $50 \%$. The numbers in parentheses are accession numbers for the DDBJ/EMBL GenBank nucleotide sequence databases.

quinones were extracted as described by Collins et al. (1984) and were analysed by HPLC and MS (Tamaoka et al., 1983; Kudo et al., 1993).

165 rDNA sequence analysis. 16S rDNA was amplified by the PCR method using a Taq DNA polymerase (Takara) and primers $20 \mathrm{~F}$ [positions 10-25, Escherichia coli numbering (Brosius et al., 1978)] and 1540R (positions 1542-1525). Amplification was carried out with a DNA thermal cycler (GeneAmp PCR system 9700; Applied Biosystems) using the following programme: $94{ }^{\circ} \mathrm{C}$ for $5 \mathrm{~min}$ followed by 30 cycles of denaturation $\left(94^{\circ} \mathrm{C}\right.$ for $\left.1 \mathrm{~min}\right)$, primer annealing $\left(55^{\circ} \mathrm{C}\right.$ for $1.5 \mathrm{~min}$ ) and primer extension $\left(72^{\circ} \mathrm{C}\right.$ for $\left.2.5 \mathrm{~min}\right)$. At the end of the cycle, the reaction mixture was kept at $72{ }^{\circ} \mathrm{C}$ for $10 \mathrm{~min}$ and then cooled to $4{ }^{\circ} \mathrm{C}$. The amplified $16 \mathrm{~S}$ rDNA fragment was purified and subjected directly to cycle sequencing by using an ABI PRISM BigDye Terminator Cycle Sequencing Ready Reaction kit (Applied Biosystems) according to the manufacturer's protocol with the following primers: $27 \mathrm{~F}, 11-27 ; 350 \mathrm{~F}, 343-357 ; 350 \mathrm{R}, 357-342 ; 780 \mathrm{~F}$, $786-803 ; 780 \mathrm{R}, 803-785 ; 1100 \mathrm{~F}, 1099-1114$; and $1492 \mathrm{R}$, 1510-1492. The conditions for thermal cycling were $96^{\circ} \mathrm{C}$ for $30 \mathrm{~s}$ followed by 25 cycles of denaturation $\left(96^{\circ} \mathrm{C}\right.$ for $10 \mathrm{~s})$, primer annealing $\left(50^{\circ} \mathrm{C}\right.$ for $\left.5 \mathrm{~s}\right)$ and primer extension $\left(60{ }^{\circ} \mathrm{C}\right.$ for $\left.4 \mathrm{~min}\right)$. The products were analysed with an $\mathrm{ABI}$ PRISM 310 Genetic Analyzer (Applied Biosystems). The sequence was multiple-aligned with the selected sequences 
(Fig. 1) obtained from the DDBJ/EMBL/GenBank databases by using the CLUSTAL $\mathrm{W}$ program package (Thompson et al., 1994); the alignment was manually verified and adjusted prior to construction of a phylogenetic tree. The phylogenetic tree was constructed by using the neighbourjoining method (Saitou \& Nei, 1987) in the PHYLIP package (Felsenstein, 1995). The confidence values of branches of the phylogenetic tree were determined by bootstrap analyses (Felsenstein, 1985) based on 1000 resamplings.

Preparation of DNA, DNA base composition and DNA-DNA hybridization. DNA was isolated from biomass by the method of Saito \& Miura (1963). Lysis of cells was performed by using achromopeptidase, crude (Wako Pure Chemical Industries) and $N$-acetylmuramidase $\mathrm{SG}$ (Seikagaku Kogyo) as well as lysozyme. The DNA G+C content was determined by the HPLC method after digestion by nuclease P1 (Yamasa Shoyu) and bacterial alkaline phosphatase (Sigma) (Tamaoka \& Komagata, 1984). An equimolar mixture of nucleotides for analysis of DNA base composition (Yamasa Shoyu) was used as the quantitative standard. The DNA-DNA hybridization experiment was carried out as described by Ezaki et al. (1989).

\section{RESULTS AND DISCUSSION}

\section{Morphological observation}

Morphology of the genera Planopolyspora and Catenuloplanes was discussed in detail in each original description (Petrolini et al., 1993a; Yokota et al., 1993). Our observations of these two genera with light and scanning electron microscopy were consistent with those in the original descriptions. Both of the type strains of $P$. crispa and C. japonica produced curly and branching sporogenous hyphae arising from the agar surface. The spores were arranged in a chain and the spore chains were aggregated into clusters. Each spore could be recognized by septation of the sporogenous hyphae in the old cultures. In these points, the modes of sporulation of the two genera were identical. A point of difference between the original descriptions of the two genera is whether the spore chains are enveloped in sporangial walls or not. Petrolini et al. (1993a) made an effort to elucidate the existence of the sporangial wall, but they mentioned that it was difficult to see the sporangial wall because the spores completely filled the sporangia and the wall tightly adhered to the spores. Only residues of the sporangial envelopes were observed after release of spores. On the other hand, Yokota et al. (1993) regarded the spores as arthrospores and did not refer to the outer sheath. As pointed out by Williams et al. (1973), definition of the term 'sporangium' is ambiguous in actinomycete morphology and even actinomycetes with spore chains (e.g. Streptomyces species) have a thin outer sheath around the spores. Also, in the case of the genera Planopolyspora and Catenuloplanes, formation of 'sporangia' remains controversial and the difference between the original descriptions of the two genera originated from a divergence of views. Therefore, we conclude that the two genera are completely identical in terms of their morphological characteristics.

\section{Chemotaxonomic characteristics}

Table 2 shows the amino acid composition in cell wall peptidoglycan, $N$-glycolyl residue contents released from muramic acid in the cell walls and whole-cell sugar patterns of the type strains of Planopolyspora and Catenuloplanes species. In the original description (Petrolini et al., 1993a), the genus Planopolyspora was characterized by the presence of meso- $\mathrm{A}_{2} \mathrm{pm}$ as a cell wall component. However, in this study, P. crispa JCM $9312^{\mathrm{T}}$ did not contain meso- $\mathrm{A}_{2} \mathrm{pm}$ but L-lysine

Table 2. Amino acid composition of cell walls, content of glycolyl residue in whole cells and whole-cell sugar patterns of the type strains of Planopolyspora and Catenuloplanes species

Gly, Glycine; Glu, glutamate; Lys, lysine; Ala, alanine; Ser, serine; Rha, rhamnose; Rib, ribose; Xyl, xylose; Mad, madurose; Ara, arabinose; Man, mannose; Glc, glucose; Gal, galactose.

\begin{tabular}{|c|c|c|c|c|c|c|c|c|c|c|c|c|c|c|}
\hline \multirow[t]{3}{*}{ Strain } & \multirow{2}{*}{\multicolumn{5}{|c|}{$\begin{array}{l}\text { Amino acids in cell wall (molar } \\
\left.\text { ratios }{ }^{*}\right)\end{array}$}} & \multirow{3}{*}{$\begin{array}{l}\text { Glycolyl residue } \\
\text { (nmol per mg } \\
\text { dried cell) }\end{array}$} & \multicolumn{8}{|c|}{ Whole-cell sugar } \\
\hline & & & & & & & \multirow[t]{2}{*}{ Rha } & \multirow[t]{2}{*}{ Rib } & \multirow[t]{2}{*}{ Xyl } & \multirow[t]{2}{*}{ Mad } & \multirow[t]{2}{*}{ Ara } & \multirow[t]{2}{*}{ Man } & \multirow[t]{2}{*}{ Glc } & \multirow[t]{2}{*}{$\mathbf{G a}$} \\
\hline & Gly & D-Glu & L-Lys & D-Ala & $\begin{array}{l}\text { L-Ser }+ \\
\text { D-Ser } \dagger\end{array}$ & & & & & & & & & \\
\hline P. crispa JCM $9312^{\mathrm{T}}$ & $1 \cdot 04$ & $1 \cdot 00$ & 0.99 & $0 \cdot 80$ & 0.95 & 103 & - & + & ++ & - & \pm & ++ & ++ & \pm \\
\hline C. atrovinosus JCM $9535^{\mathrm{T}}$ & 1.03 & $1 \cdot 00$ & 0.99 & 0.79 & 0.91 & 98 & - & + & ++ & - & - & + & ++ & + \\
\hline C. castaneus JCM 9537 & 1.07 & 1.00 & 0.99 & 0.79 & 0.99 & 90 & \pm & ++ & ++ & - & \pm & ++ & ++ & \pm \\
\hline C. indicus JCM $9534^{\mathrm{T}}$ & 1.02 & $1 \cdot 00$ & 0.91 & 0.78 & $1 \cdot 03$ & 73 & - & + & ++ & - & \pm & + & + & \pm \\
\hline C. japonicus JCM $9106^{\mathrm{T}}$ & 1.07 & 1.00 & 0.99 & $0 \cdot 80$ & 0.96 & 94 & \pm & ++ & ++ & - & \pm & ++ & \pm & \pm \\
\hline C. nepalensis JCM $9536^{\mathrm{T}}$ & 1.04 & $1 \cdot 00$ & 0.97 & 0.88 & $1 \cdot 05$ & 79 & - & + & ++ & - & \pm & + & \pm & \pm \\
\hline C. niger JCM $9533^{\mathrm{T}}$ & 1.07 & 1.00 & 0.99 & 0.87 & $1 \cdot 10$ & 69 & - & + & ++ & - & - & + & ++ & \pm \\
\hline
\end{tabular}

* Molar ratios were represented with glutamic acid as a unit.

$\uparrow$ The molar ratio of $\mathrm{D}$-serine to L-serine was ca. $0 \cdot 3$. 
Catenuloplanes crispus comb. nov.

Table 3. Menaquinone composition of the type strain of Planopolyspora and Catenuloplanes species

\begin{tabular}{|c|c|c|c|c|c|c|c|c|}
\hline \multirow[t]{2}{*}{ Strain } & \multicolumn{8}{|c|}{ Menaquinone composition (\%) } \\
\hline & MK-10 & MK-10 $\left(\mathrm{H}_{2}\right)$ & MK-10( $\left(\mathrm{H}_{4}\right)$ & MK-10(Ho & $\mathrm{MK}-10\left(\mathrm{H}_{8}\right)$ & $\operatorname{MK-11}\left(\mathbf{H}_{2}\right)$ & $\operatorname{MK-11}\left(\mathrm{H}_{4}\right)$ & MK-11( $\left(\mathrm{H}_{6}\right)$ \\
\hline P. crispa JCM $9312^{\mathrm{T}}$ & 2 & 7 & 55 & 13 & 2 & 3 & 14 & 4 \\
\hline C. atrovinosus JCM $9535^{\mathrm{T}}$ & 2 & 8 & 51 & 6 & 1 & 5 & 23 & 4 \\
\hline C. castaneus $\mathrm{JCM} 9537^{\mathrm{T}}$ & 3 & 5 & 68 & 6 & 0 & 1 & 14 & 2 \\
\hline C. indicus JCM 9534 & 2 & 10 & 61 & 4 & 0 & 3 & 17 & 2 \\
\hline C. japonicus JCM 9106 & 6 & 14 & 55 & 8 & 1 & 4 & 11 & 2 \\
\hline C. nepalensis JCM $9536^{\mathrm{T}}$ & 4 & 12 & 22 & 0 & 0 & 29 & 29 & 1 \\
\hline C. niger JCM $9533^{\mathrm{T}}$ & 2 & 3 & 56 & 7 & 1 & 2 & 25 & 4 \\
\hline
\end{tabular}

Table 4. Cellular fatty acid composition of the type strains of Planopolyspora and Catenuloplanes species

\begin{tabular}{|c|c|c|c|c|c|c|c|c|c|c|c|c|c|c|c|c|}
\hline \multirow[t]{3}{*}{ Strain } & \multicolumn{16}{|c|}{ Fatty acid composition $(\%)^{*}$} \\
\hline & \multicolumn{9}{|c|}{ Normal } & \multicolumn{6}{|c|}{ Iso-branched } & \multirow{2}{*}{$\begin{array}{c}\begin{array}{c}\text { Anteiso- } \\
\text { branched }\end{array} \\
17: 0\end{array}$} \\
\hline & $14: 0$ & $15: 0$ & $16: 0$ & $16: 1$ & $17: 0$ & 18:0 & 18:1 & $19: 0$ & 19:1 & $15: 0$ & $16: 0$ & $17: 0$ & $17: 1$ & $18: 1$ & 19:0 & \\
\hline P. crispa JCM $9312^{\mathrm{T}}$ & 1 & 1 & 14 & 2 & 11 & 5 & 25 & TR & 1 & TR & 15 & 4 & 0 & 1 & TR & 19 \\
\hline C. atrovinosus JCM $9535^{\mathrm{T}}$ & TR & 1 & 9 & 1 & 8 & 6 & 17 & TR & 1 & TR & 9 & 9 & 1 & 1 & 1 & 34 \\
\hline C. castaneus JCM $9537^{\mathrm{T}}$ & 1 & TR & 35 & 10 & 2 & 7 & 32 & TR & TR & TR & 5 & TR & 0 & 0 & 0 & 8 \\
\hline C. indicus JCM $9534^{\mathrm{T}}$ & 1 & 1 & 13 & 1 & 14 & 7 & 27 & 1 & 2 & 1 & 6 & 6 & TR & TR & 1 & 18 \\
\hline C. japonicus JCM 9106 & 1 & 1 & 40 & 8 & 5 & 9 & 29 & TR & 0 & TR & 1 & 1 & 0 & 0 & 0 & 5 \\
\hline C. nepalensis JCM 9536' & 1 & 1 & 21 & 2 & 10 & 16 & 36 & TR & 1 & $\mathrm{TR}$ & TR & 3 & 0 & TR & TR & 7 \\
\hline C. niger JCM $9533^{\mathrm{T}}$ & TR & TR & 12 & 1 & 7 & 11 & 33 & 1 & 2 & TR & 3 & 9 & TR & $\mathrm{TR}$ & 1 & 19 \\
\hline
\end{tabular}

TR, Trace amount $(<0.5 \%)$.

* Fatty acid nomenclature: number of carbon atoms: number of double bonds.

and L-serine with a small amount of D-serine, which have been reported as peculiarities of the genera Catenuloplanes (Yokota et al., 1993) and Couchioplanes (Tamura et al., 1994). P. crispa JCM $9312^{\mathrm{T}}$ had $N$-glycolated muramic acid in the peptidoglycan in common with members of the genus Catenuloplanes and other genera belonging to the family Micromonosporaceae. A diagnostic sugar of $P$. crispa JCM $9312^{\mathrm{T}}$ was xylose, which is also characteristic of members of the Micromonosporaceae; madurose, which was reported to be present in the original description, was not detected. This fact means that the basis on which the original authors classified the genus Planopolyspora into the 'maduromycete' group is lost. The isoprenoid quinones of $P$. crispa $\mathrm{JCM} 9312^{\mathrm{T}}$ were mainly composed of $\mathrm{MK}-10\left(\mathrm{H}_{4}\right)$ and $\mathrm{MK}-11\left(\mathbf{H}_{4}\right)$, as shown in Table 3. Although this menaquinone profile does not coincide with profiles of Catenuloplanes species, which were reported to contain MK-9 $\left(\mathbf{H}_{8}\right)$ and MK-10 $\left(\mathbf{H}_{8}\right)$ by Yokota et al. (1993) and Tamura et al. (1995), our MS analyses revealed that all Catenuloplanes strains also had MK-10 $\left(\mathrm{H}_{4}\right)$ and $\mathrm{MK}-11\left(\mathrm{H}_{4}\right)$ as major components (Table 3 ). Table 4 shows the cellular fatty acid composition of the type strains of $P$. crispa and Catenuloplanes species and all of the strains tested showed the similar patterns with minor variations. $P$. crispa JCM $9312^{\mathrm{T}}$ had phosphatidylcholine as a diagnostic phospholipid [phospholipid type PIII of Lechevalier et al. (1977)] and no mycolic acids.

The type strain of $P$. crispa shared cell wall amino acid and whole-cell sugar compositions with the genera Catenuloplanes and Couchioplanes, but the genus Couchioplanes obviously differs from the other two genera in morphological characteristics and profiles of menaquinones and phospholipids (Couchioplanes strains have no phosphatidylcholine).

\section{S rDNA sequence analysis}

The $1440 \mathrm{nt}$ of the 16S rDNA of Planopolyspora crispa JCM $9312^{\mathrm{T}}$ were sequenced and compared with sequences of selected members of the family Micromonosporaceae (Fig. 1). The data set used for construction of the phylogenetic tree contained $1411 \mathrm{nt}$ positions of each sequence as a result of elimination of 
Table 5. DNA base composition and DNA-DNA relatedness among the type strains of Planopolyspora crispa and Catenuloplanes species

\begin{tabular}{|c|c|c|c|c|c|c|c|c|}
\hline \multirow[t]{2}{*}{ Strain } & \multirow{2}{*}{$\underset{(\mathrm{mol} \%)}{G+C \text { content }}$} & \multicolumn{7}{|c|}{ DNA complementarity (\%) with labelled DNA from: } \\
\hline & & \multicolumn{7}{|c|}{ 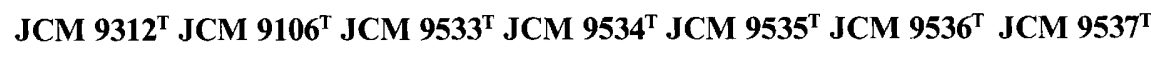 } \\
\hline P. crispa JCM $9312^{\mathrm{T}}$ & $70 \cdot 0$ & 100 & 59 & 42 & 28 & 47 & 44 & 47 \\
\hline C. japonicus JCM $9106^{\mathrm{T}}$ & $70 \cdot 0$ & 42 & 100 & 34 & 24 & 37 & 40 & 42 \\
\hline C. niger JCM $9533^{\mathrm{T}}$ & $71 \cdot 2$ & 45 & 47 & 100 & 39 & 54 & 56 & 49 \\
\hline C. indicus JCM $9534^{\mathrm{T}}$ & $70 \cdot 4$ & 37 & 37 & 52 & 100 & 44 & 48 & 39 \\
\hline C. atrovinosus $\mathrm{JCM} 9535^{\mathrm{T}}$ & $71 \cdot 5$ & 40 & 44 & 42 & 31 & 100 & 50 & 50 \\
\hline C. nepalensis JCM $9536^{\mathrm{T}}$ & $70 \cdot 3$ & 37 & 44 & 45 & 34 & 46 & 100 & 50 \\
\hline C. castaneus JCM $9537^{\mathrm{T}}$ & $71 \cdot 3$ & 39 & 48 & 38 & 28 & 46 & 41 & 100 \\
\hline
\end{tabular}

gaps and ambiguous nucleotides from the sequences between positions 34 and 1491 (Escherichia coli position number). As shown in Fig. 1, P . crispa JCM $9312^{\mathrm{T}}$ was closely related to $C$. japonicus and these two organisms formed a coherent cluster supported by a high bootstrap value $(98 \%)$. The level of $16 \mathrm{~S}$ rDNA sequence similarity between $P$. crispa $\mathrm{JCM} 9312^{\mathrm{T}}$ and C. japonicus was $98.0 \%$.

Coincidence of the morphological and chemotaxonomic characteristics between the genera Planopolyspora and Catenuloplanes and the result of phylogenetic analysis indicate that these two genera should be incorporated into one genus, Catenuloplanes, which has priority over the genus Planopolyspora [Bacteriological Code 1990 Revision, rule 24b (2)].

\section{DNA hybridization and physiology}

Table 5 shows comparisons of DNA base composition and levels of DNA relatedness among the type strains of the genera Planopolyspora and Catenuloplanes. The levels of the DNA relatedness between $P$. crispa JCM $9312^{\mathrm{T}}$ and Catenuloplanes strains were $28-59 \%$. These values correspond to those observed among the previously described species of the genus Catenuloplanes $(24-56 \%)$. As shown in Table 1, P. crispa JCM 9312 was distinguishable from the type strains of the genus Catenuloplanes by physiological and biological aspects, particularly decomposition of elastin and testosterone, utilization of methyl $\alpha$-D-glucoside and D-raffinose, tolerance to ampicillin, benzylpenicillin and cephalexin, and acid production from melibiose and D-ribose. Therefore, P. crispa should be transferred to the genus Catenuloplanes as an independent species for which the name Catenuloplanes crispus comb. nov. is proposed.

\section{Amended description of the genus Catenuloplanes Yokota et al. 1993}

The amended description below is based on data from Yokota et al. (1993), Petrolini et al. (1993a) and this study. Aerobic, Gram-positive and non-acid-fast.
Forms non-fragmenting and branched vegetative hyphae. Aerial mycelium is rudimentarily developed or absent. Spores, if produced, are arranged in chains, which arise from the vegetative hyphae or are formed on the rudimentary aerial hyphae. The spore chains are aggregated into clusters and may be enveloped by outer sheaths. The configuration of spore chains is curly or spiral with one or two turns and sometimes branched. The spores are rod-shaped, straight or curved with smooth surfaces, and become motile by peritrichous flagella after release into water. The cell wall peptidoglycan contains glycine, D-glutamate, Llysine, D-alanine and $\mathrm{L}$-serine in a ratio of $1: 1: 1: 0 \cdot 8: 1$ and lacks diaminopimelic acid. The muramic acid in the glycan moiety is $N$-glycolated. The whole-cell hydrolysate contains xylose, mannose, glucose and ribose, and lacks madurose. The predominant menaquinones are $\mathrm{MK}-10\left(\mathrm{H}_{4}\right)$ and $\mathrm{MK}-11\left(\mathrm{H}_{4}\right)$ and, in some strains, MK-10, MK-10( $\left.\mathrm{H}_{2}\right), \mathrm{MK}-10\left(\mathrm{H}_{6}\right)$, MK$10\left(\mathrm{H}_{8}\right), \mathrm{MK}-11\left(\mathrm{H}_{2}\right)$ and $\mathrm{MK}-11\left(\mathrm{H}_{6}\right)$ are also present as minor components. The diagnostic phospholipid is phosphatidylcholine. The cellular fatty acid was composed of hexadecanoic, octadecanoic, octadecenoic and 14-methylhexadecanoic acids. Hexadecenoic, heptadecanoic and 14-methylpentadecanoic acids are also detected as major components in some strains. Mycolic acids are absent. The $\mathrm{G}+\mathrm{C}$ content of the DNA is $70-72 \mathrm{~mol} \%$. The type species is Catenuloplanes japonicus.

\section{Description of Catenuloplanes crispus (Petrolini et al. 1993) comb. nov. (basonym Planopolyspora crispa)}

Catenuloplanes crispus (cri'spus. L. adj. crispus curly).

Vegetative mycelia are yellow to brown on most media. Yellowish diffusible pigment is produced in glycerol/ asparagine agar. Decomposes casein, elastin, aesculin, testosterone and urea, but not adenine, DNA, hypoxanthine, tyrosine or xanthine. Utilizes L-arabinose, Dcellobiose, D-fructose, D-galactose, D-glucose, glycerol, myo-inositol, D-lactose, maltose, D-mannitol, Dmannose, L-rhamnose, salicin, starch, sucrose, Dtrehalose and D-xylose as a sole carbon source, but not 
adonitol, dulcitol, $i$-erythritol, D-melezitose, methyl $\alpha$ $D$-glucoside or D-raffinose. Utilizes fumarate, L-malate and succinate, but not benzoate, citrate, mucate, oxalate or L-tartrate. Produces acids from L-arabinose, D-fructose, D-galactose, D-glucose, myo-inositol, Lrhamnose, sucrose and D-xylose, but not from Dmelezitose, melibiose, methyl $\alpha$-D-glucoside, Draffinose, D-ribose or L-sorbose. No growth in the presence of $2 \%(\mathrm{w} / \mathrm{v}) \mathrm{NaCl}$. Susceptible to antibiotics $\left(20 \mu \mathrm{g} \mathrm{ml}^{-1}\right)$ : ampicillin, benzylpenicillin, cephalexin, novobiocin and kanamycin. Mesophilic. Monotypic. The DNA G $+\mathrm{C}$ content is $70 \mathrm{~mol} \%$. The type strain is strain JCM $9312^{\mathrm{T}}\left(=\right.$ ATCC $51431^{\mathrm{T}}=$ DSM $44128^{\mathrm{T}}$ $=$ IFO $15622^{\mathrm{T}}=\operatorname{IPV} 2867^{\mathrm{T}}=\mathrm{NCB} 1173^{\mathrm{T}}$ ).

\section{ACKNOWLEDGEMENTS}

We thank M. Chijimatsu, Division of Biomolecular Characterization, The Institute of Physical and Chemical Research (RIKEN), for analysing the amino acid composition of cell wall peptidoglycan. We also thank B. Petrolini, Institute of Plant Pathology, University of Milan, for providing the type strain of Planopolyspora crispa.

\section{REFERENCES}

Brosius, J., Palmer, M. L., Kennedy, P. J. \& Noller, H. F. (1978). Complete nucleotide sequence of a $16 \mathrm{~S}$ ribosomal RNA gene from Escherichia coli. Proc Natl Acad Sci USA 75, 4801-4805.

Collins, M. D., Faulkner, M. \& Keddie, R. M. (1984). Menaquinone composition of some sporeforming actinomycetes. Syst Appl Microbiol 5, 20-29.

Einarsson, S. \& Josefsson, B. (1987). Separation of amino acid enantiomers and chiral amines using precolumn derivatization with (+)-1-(9-fluorenyl)ethyl chloroformate and reversedphase liquid chromatography. Anal Chem 59, 1191-1195.

Ezaki, T., Hashimoto, Y. \& Yabuuchi, E. (1989). Fluorometric deoxyribonucleic acid-deoxyribonucleic acid hybridization in microdilution wells as an alternative to membrane filter hybridization in which radioisotopes are used to determine genetic relatedness among bacterial strains. Int $J$ Syst Bacteriol 39, $224-229$

Felsenstein, J. (1985). Confidence limits on phylogenies: an approach using the bootstrap. Evolution 39, 783-791.

Felsenstein, J. (1995). PHYLIP (phylogenetic inference package), version $3.57 \mathrm{c}$. Seattle: Department of Genetics, University of Washington.

Goodfellow, M. (1989). Maduromycetes. In Bergey's Manual of Systematic Bacteriology, vol. 4, pp. 2509-2551. Edited by S. T. Williams, M. E. Sharpe \& J. G. Holt. Baltimore: Williams \& Wilkins.

Gordon, R. E., Barnett, D. A., Handerhan, J. E. \& Pang, C. H.-N. (1974). Nocardia coeliaca, Nocardia autotrophica, and the nocardin strain. Int J Syst Bacteriol 24, 54-63.

Itoh, T., Kudo, T., Parenti, F. \& Seino, A. (1989). Amended description of the genus Kineosporia, based on chemotaxonomic and morphological studies. Int J Syst Bacteriol 39, 168-173.

Jacobson, E., Grauville, W. C. \& Fogs, C. E. (1958). Color Harmony Manual, 4th edn. Chicago: Container Corporation of America.

Kawamoto, l., Oka, T. \& Nara, T. (1981). Cell wall composition of Micromonospora olivoasterospora, Micromonospora sagamiensis, and related organisms. J Bacteriol 146, 527-534.
Koch, C., Kroppenstedt, R. M., Rainey, F. A. \& Stackebrandt, E. (1996). 16S ribosomal DNA analysis of the genera Micromonospora, Actinoplanes, Catellatospora, Catenuloplanes, Couchioplanes, Dactylosporangium, and Pilimelia and emendation of the family Micromonosporaceae. Int $J$ Syst Bacteriol 46, 765-768.

Kudo, T., Itoh, T., Miyadoh, S., Shomura, T. \& Seino, A. (1993). Herbidospora gen. nov., a new genus of the family Streptosporangiaceae Goodfellow et al. 1990. Int I Syst Bacteriol 43, 319-328

Lechevalier, M. P. \& Lechevalier, H. (1970). Chemical composition as a criterion in the classification of aerobic actinomycetes. Int J Syst Bacteriol 20, 435-443.

Lechevalier, M. P., De Bievre, C. \& Lechevalier, H. (1977). Chemotaxonomy of aerobic actinomycetes: phospholipid composition. Biochem Syst Ecol 5, 249-260.

Mikami, H. \& Ishida, Y. (1983). Post-column fluorometric detection of reducing sugars in high-performance liquid chromatography using arginine. Bunseki Kagaku 32, E207E210.

Minnikin, D. E., O'Donnell, A. G., Goodfellow, M., Alderson, G., Athalye, M., Schaal, A. \& Parlett, J. H. (1984). An integrated procedure for the extraction of bacterial isoprenoid quinones and polar lipids. J Microbiol Methods 2, 233-241.

Petrolini, B., Quaroni, S., Saracchi, M. \& Sardi, P. (1993a). A new genus of the maduromycetes: Planopolyspora gen. nov. Actinomycetes 4, 8-16.

Petrolini, B., Quaroni, S., Saracchi, M. \& Sardi, P. (1993b). Validation of the publication of new names and new combinations previously effectively published outside the IJSB List no. 47. Int $J$ Syst Bacteriol 43, 864-865.

Saito, H. \& Miura, K. (1963). Preparation of transforming deoxyribonucleic acid by phenol treatment. Biochim Biophys Acta 72, 619-629.

Saitou, N. \& Nei, M. (1987). The neighbor-joining method: a new method for reconstructing phylogenetic trees. Mol Biol Evol 4, 406-425.

Stevenson, I. L. (1967). Utilization of aromatic hydrocarbons by Arthrobacter spp. Can J Microbiol 13, 205-211.

Suzuki, K. \& Komagata, K. (1983). Taxonomic significance of cellular fatty acid composition in some coryneform bacteria. Int $J$ Syst Bacteriol 33, 188-200

Tamaoka, J. \& Komagata, K. (1984). Determination of DNA base composition by reversed-phase high-performance liquid chromatography. FEMS Microbiol Lett 25, 125-128.

Tamaoka, J., Katayama-Fujimura, Y. \& Kuraishi, H. (1983). Analysis of bacterial menaquinone mixtures by high performance liquid chromatography. $J$ Appl Bacteriol 54, 31-36.

Tamura, T., Nakagaito, Y., Nishii, T., Hasegawa, T., Stackebrandt, E. \& Yokota, A. (1994). A new genus of the order Actinomycetales, Couchioplanes gen. nov., with descriptions of Couchioplanes caeruleus (Horan and Brodsky 1986) comb. nov. and Couchioplanes caeruleus subsp. azureus subsp. nov. Int J Syst Bacteriol 44, 193-203.

Tamura, T., Yokota, A., Huang, L. H., Hasegawa, T. \& Hatano, K. (1995). Five new species of the genus Catenuloplanes: Catenuloplanes niger sp. nov., Catenuloplanes indicus sp. nov., Catenuloplanes atrovinosus sp. nov., Catenuloplanes castaneus sp. nov., and Catenuloplanes nepalensis sp. nov. Int J Syst Bacteriol 45, 858-860.

Thompson, J. D., Higgins, D. G. \& Gibson, T. J. (1994). CLUSTAL $\mathrm{W}$ : improving the sensitivity of progressive multiple sequence 
alignment through sequence weighting, position specific gap penalties and weight matrix choice. Nucleic Acids Res 22, $4673-4680$.

Uchida, K. \& Aida, K. (1984). An improved method for the glycolate test for simple identification of the acyl type of bacterial cell walls. J Gen Appl Microbiol 30, 131-134.

Williams, S. T., Sharples, G. P. \& Bradshaw, R. M. (1973). The fine structure of the Actinomycetales. In Actinomycetales: Characteristics and Practical Importance, pp. 113-136. Edited by G. Sykes \& F. A. Skinner. London: Academic Press.

Yokota, A., Tamura, T., Hasegawa, T. \& Huang, L. H. (1993). Catenuloplanes japonicus gen. nov., sp. nov., nom. rev., a new genus of the order Actinomycetales. Int $J$ Syst Bacteriol 43, $805-812$. 